\title{
Environmental life cycle assessment (LCA) as a tool for identification and assessment of environmental aspects in environmental management systems (EMS)
}

\author{
Part 2: case studies
}

\author{
Anna Lewandowska • Alina Matuszak-Flejszman • \\ Katarzyna Joachimiak • Andreas Ciroth
}

Received: 28 January 2010 / Accepted: 18 January 2011 /Published online: 1 February 2011

(C) The Author(s) 2011. This article is published with open access at Springerlink.com

\begin{abstract}
Purpose The paper presents a discussion on the possibilities of using LCA in identification and assessment of environmental aspects in environmental management systems based on the requirements of the international ISO14001 standard and the European Union EMAS regulation. Some modifications of LCA methodology are proposed in Part 1 while the results of a review of environmental aspects for 36 organisations with implemented EMS are presented in Part 2 of the article.

Materials and methods The scope of the systems analysed in EMS and in LCA is different. This comes as the result of the fact that both ISO 14001 and EMAS are focused on an organisation on contrary to ISO14040x which are focused on a product life cycle. For the present work, this resulted in a need of adjusting the LCA methodology to EMS specificity and vice versa. Some suggestions of such modifications are presented and discussed in the paper. Results A preliminary analysis was carried out on 36
\end{abstract}

Responsible editor: David Pennington

A. Lewandowska $(\bowtie) \cdot \mathrm{K}$. Joachimiak

Product Ecology Department, Faculty of Commodity Science, Poznan University of Economics,

Niepodleglosci av. 10,

61-875 Poznan, Poland

e-mail: anna.lewandowska@ue.poznan.pl

A. Matuszak-Flejszman

Department of Standardized Management Systems,

Poznan University of Economics,

Niepodleglosci av. 10,

61-875 Poznan, Poland

A. Ciroth

GreenDeltaTC GmbH,

Raumerstrasse 7 ,

10437 Berlin, Germany organisations which have environmental management systems compliant with the ISO14001 or EMAS regulations. A certain disproportion between input and output related environmental aspects included in most of the analysed registers was found. The probable reasons for such disproportion could be the fact that the output related environmental aspects are easier to manage by organisation and are often regulated by laws. Legal requirements are a significant criterion in the environmental aspects assessment.

Discussion Based on the assessments carried out and the observations made, some conclusions have been drawn with regard to weaknesses and strengths and usefulness of LCA, as a result of a comparison to the traditional approaches used in EMS in the discussed area. LCA has evident advantages like: standardised methodology, possibility of inclusion of the quantitative information, presence of some methodological steps enabling the verification of the collected data, and ability to generate of reproducible results. At the same time, the following potential weak points can be observed: a complexity of the procedure, higher time, and cost requirements (especially related to an inventory phase); difficulties with assessing of environmental aspects with the qualitative character and these related to emergency situations; and limitation related to the lack of relevant characterisation factors in the currently used life cycle impact assessment methods.

Conclusions LCA ought to be considered as a tool used for identification and assessment of environmental aspects in environmental management systems. The listed limitations do not disqualify its suitability to be used. After certain simplifications, LCA seems to be a valuable alternative to the methodologies currently in use.

Keywords Environmental aspects · EMS · LCA · Identification · Assessment 


\section{Introduction}

Part 1 of this article focuses on the theoretical possibilities of using LCA in identification and assessment of environmental aspects in environmental management systems based on the requirements of the international ISO14001 standard (2004) and the European Union EMAS regulation (2008). This part presents the results of a review of environmental aspects for 36 organisations with implemented EMS, and the results of identification and assessment of the aspects for a selected example with regards to the use of LCA. The obtained information will be compared with the results obtained from traditional approaches.

\section{Studies}

A preliminary analysis was carried out on 36 organisations which have environmental management systems compliant with the ISO14001 or EMAS regulations. Twenty of these operated from Poland, and the remaining ones operated from Germany. The data had been provided by consulting companies or had been extracted from the documents provided by the organisations (environmental aspects registers, EMAS environmental declarations). The following data was found of interest from the point of view of the assessments: the type of EMS in an organisation, environmental aspects registers including results of their assessments, as well as quantitative data regarding each aspect. The analysis of the collected information was divided into three areas:

- General characteristic of collected data

- LCA-based assessment of environmental aspects identified with accordance to "traditional" methodology used typically within EMS (non-LCA-based identification, LCA-based assessment)

- Identification and assessment of environmental aspects with the use of LCA (LCA-based identification, LCA-based assessment)

\subsection{General characteristics of environmental aspects' registers}

Within the first step, a review of the available documents and environmental aspects registered in them with regard to coherency with LCA methodology was carried out. The main issues of focus were:

- The structure of environmental aspects. Usually less attention (than in LCA) is paid to balancing of processes and data completeness, it is possible that a clear disproportion of inputs and outputs would appear. As a result, an analysis of the structure of aspects and their co-relations (including data quality and consistency aspects) may be a source of valuable information and be the method of their verification.

- The possibility of taking into account indirect environmental aspects (which play a key role especially in EMAS)

- The possibility of taking into account environmental aspects and results from registers in LCA analyse

The general characteristics of the analysed registers have been presented in Table 1 (Polish examples) and in Table 2 (German examples). The organisations have been described by type of economic activity (according to the Statistical Classification of Economic Activities in the European Community NACE, presented in Table 3) and their type of EMS.

The companies can set up the identification procedure and assessment criteria individually, so some differences can exist between particular organisations. Assessment criteria used in the analysed companies are for example:

- Legal requirements

- Interested parties (including local society)

- Costs

- Presence of the aspect in the environmental policy

- Exceed the limits included in the environmental permits

- Impact on companies' image

- Environmental criterion

The environmetal criterion can be related to the aspect or " $t$ " the impact. The environmental criteria used in the analysed companies included at least one of the following elements recommended by the ISO 14004 standard (International Standard Organization (2004) ISO 14004):

- Size of the aspect

- Frequency of the aspect

- Duration of the impact

- Toxicity (severity) of the impact

- Scale of the impact

Especially in Polish cases, a certain disproportion can be observed in inclusion of input and output environmental aspects. The output elements were the majority and formed on average $73.76 \%$ of a total number of aspects. In cases from Germany, this relation was rather balanced and this kind of disproportion has not been observed. However, these results were formulated basing on average values and did not reflect fully a situation of each individual organisation. Because of significant differences between analysed companies, a level of dispersion included in the sample should be recognised as high.

Input aspects that were considered coincided usually with each other and included the use of main resources like: water, electric energy, energy conductors or transport fuel. It 
Table 1 General characteristics of environmental aspects (organisations operating from Poland)

\begin{tabular}{|c|c|c|c|c|c|c|c|c|c|}
\hline \multirow{3}{*}{$\begin{array}{l}\text { Number } \\
\text { of organisation }\end{array}$} & \multirow{3}{*}{$\begin{array}{l}\text { Symbol } \\
\text { of NACE }\end{array}$} & \multirow{3}{*}{$\begin{array}{l}\text { Type } \\
\text { of EMS }\end{array}$} & \multirow{3}{*}{$\begin{array}{l}\text { Total number } \\
\text { of aspects }\end{array}$} & \multicolumn{6}{|c|}{ Aspects description } \\
\hline & & & & \multicolumn{4}{|l|}{ Type } & \multicolumn{2}{|l|}{ Character } \\
\hline & & & & $\begin{array}{l}\text { Significant } \\
\%\end{array}$ & $\begin{array}{l}\text { Input related } \\
\%\end{array}$ & $\begin{array}{l}\text { Output related } \\
\%\end{array}$ & $\begin{array}{l}\text { Others } \\
\%\end{array}$ & $\begin{array}{l}\text { Quantitative } \\
\%\end{array}$ & $\begin{array}{l}\text { Qualitative } \\
\%\end{array}$ \\
\hline 1 & $\mathrm{C}$ & ISO 14001 & 84 & 26.19 & 10.71 & 89.29 & 0.00 & 94.05 & 5.95 \\
\hline 2 & $\mathrm{O}$ & ISO 14001 & 13 & 46.15 & 61.54 & 38.46 & 0.00 & 100.00 & 0.00 \\
\hline 3 & $\mathrm{~B}$ & ISO 14001 & 10 & 40.00 & 10.00 & 80.00 & 10.00 & 80.00 & 20.00 \\
\hline 4 & $\mathrm{C}$ & ISO 14001 & 87 & 31.03 & 17.24 & 78.16 & 4.60 & 95.40 & 4.59 \\
\hline 5 & $\mathrm{E}$ & ISO 14001 & 19 & 52.63 & 15.79 & 84.21 & 0.00 & 100.00 & 0.00 \\
\hline 6 & $\mathrm{E}$ & ISO 14001 & 23 & 26.09 & 0.00 & 100.00 & 0.00 & 95.65 & 4.348 \\
\hline 7 & $\mathrm{O}$ & ISO 14001 & 24 & 45.83 & 25.00 & 75.00 & 0.00 & 100.00 & 0.00 \\
\hline 8 & $\mathrm{O}$ & ISO 14001 & 36 & 52.78 & 19.44 & 80.56 & 0.00 & 88.88 & 11.11 \\
\hline 9 & $\mathrm{C}$ & EMAS & 32 & 31.25 & 37.50 & 43.75 & 18.75 & 81.25 & 18.75 \\
\hline 10 & 0 & EMAS & 13 & 76.92 & 38.46 & 46.15 & 15.38 & 84.61 & 15.38 \\
\hline 11 & $\mathrm{C}$ & EMAS & 18 & 72.22 & 50.00 & 38.89 & 11.11 & 83.33 & 16.66 \\
\hline 12 & $\mathrm{D}$ & ISO 14001 & 65 & 20.00 & 9.23 & 64.62 & 26.15 & 84.61 & 15.38 \\
\hline 13 & $\mathrm{E}$ & ISO 14001 & 41 & 12.20 & 12.20 & 78.05 & 9.76 & 92.68 & 7.32 \\
\hline 14 & B & ISO 14001 & 97 & 9.28 & 8.25 & 83.51 & 8.25 & 95.87 & 4.12 \\
\hline 15 & $\mathrm{D}$ & ISO 14001 & 75 & 24.00 & 12.00 & 80.00 & 8.00 & 94.66 & 5.33 \\
\hline 16 & Q & ISO 14001 & 30 & 46.67 & 13.33 & 80.00 & 6.67 & 93.33 & 6.66 \\
\hline 17 & $\mathrm{D}$ & ISO 14001 & 53 & 13.21 & 15.09 & 71.70 & 13.21 & 90.56 & 9.43 \\
\hline 18 & $\mathrm{H}$ & EMAS & 47 & 61.70 & 8.51 & 91.49 & 0.00 & 91.49 & 8.51 \\
\hline 19 & $\mathrm{C}$ & ISO 14001 & 29 & 31.03 & 17.24 & 75.86 & 6.90 & 93.10 & 6.89 \\
\hline 20 & $\mathrm{E}$ & ISO 14001 & 22 & 31.82 & 4.55 & 95.45 & 0.00 & 100.00 & 0.00 \\
\hline Mean & & & 40.90 & 37.55 & 19.30 & 73.76 & 8.16 & 91.98 & 8.02 \\
\hline
\end{tabular}

has been noted that, most probably as the result of a qualitative approach and the lack of the need of mass balancing, outputs are not considered with inputs, which would be unacceptable in a LCA approach. In a number of cases, it has been stated that the registered waste did not have their counterparts in the input, e.g. used fluorescent lamps classified as output aspects were not associated with having to replace and use a new ones; the production of these also bears certain environmental consequences and in accordance with LCA it should be presented as the input element. It seems that there are three main causes of focusing on to output aspects in approaches traditionally used for their identification in EMS and observed especially in Polish cases.

- The presence of legal requirements with regard to output related environmental aspects

- The problem of managing input related environmental aspects

- The problem of identifying the impact of input related environmental aspects

The output related environmental aspects, which mainly include waste and emissions, are regulated by laws which are a significant criterion in the environmental aspects assessment. Taking into account that the organisation operates within certain legal conditions and is obliged to adhere to a number of regulations it is understandable and reasonable that the identification is focused on these elements. It does not however explain fully the omission of some of the input elements. The problem might lie in the difficulty of their management. To a large extent, they do include materials and semiproducts produced by suppliers. And these, as key production materials include suppliers' technology, are beyond the remit of an organisation and belong therefore to the indirect aspects. Whilst using LCA, it is possible to take into account suppliers' technology and registering of the environmental impacts related to the activities of suppliers. If, however, the assessments were to be credible, they should be carried out based on environmental data provided by the same suppliers or based on the data collected from secondary sources (e.g., data bases) after a thorough assessment of its quality. The advantage of such a solution is taking into account the indirect environmental aspects, significant especially in EMAS. In a way, LCA would be in this context a tool for assessment of suppliers, providing that these were willing to be assessed. An organisation might impact technologies used 
Table 2 General characteristics of environmental aspects (organisations operating from Germany)

\begin{tabular}{|c|c|c|c|c|c|c|c|c|c|}
\hline \multirow{3}{*}{$\begin{array}{l}\text { Number } \\
\text { of organisation }\end{array}$} & \multirow{3}{*}{$\begin{array}{l}\text { Symbol } \\
\text { of NACE }\end{array}$} & \multirow{3}{*}{$\begin{array}{l}\text { Type } \\
\text { of EMS }\end{array}$} & \multirow{3}{*}{$\begin{array}{l}\text { Total number } \\
\text { of aspects }\end{array}$} & \multicolumn{6}{|c|}{ Aspects description } \\
\hline & & & & \multicolumn{4}{|l|}{ Type } & \multicolumn{2}{|l|}{ Character } \\
\hline & & & & $\begin{array}{l}\text { Significant } \\
\%\end{array}$ & $\begin{array}{l}\text { Input related } \\
\%\end{array}$ & $\begin{array}{l}\text { Output related } \\
\%\end{array}$ & $\begin{array}{l}\text { Others } \\
\%\end{array}$ & $\begin{array}{l}\text { Quantitative } \\
\%\end{array}$ & $\begin{array}{l}\text { Qualitative } \\
\%\end{array}$ \\
\hline 1 & $\mathrm{P}$ & EMAS + ISO 14001 & 18 & 27.78 & 33.33 & 55.56 & 11.11 & 55.56 & 44.44 \\
\hline 2 & $\mathrm{C}$ & EMAS + ISO 14001 & 65 & 7.69 & 29.23 & 38.46 & 32.31 & 76.92 & 23.08 \\
\hline 3 & $\mathrm{D}$ & EMAS + ISO 14001 & 17 & 35.29 & 11.76 & 52.94 & 35.29 & 70.59 & 29.41 \\
\hline 4 & $\mathrm{O}$ & EMAS + ISO 14001 & 8 & 25.00 & 62.50 & 25.00 & 12.50 & 87.50 & 12.50 \\
\hline 5 & $\mathrm{C}$ & EMAS + ISO 14001 & 14 & 50.00 & 28.57 & 42.86 & 21.43 & 85.71 & 14.29 \\
\hline 6 & $\mathrm{P}$ & EMAS + ISO 14001 & 18 & 72.22 & 38.89 & 61.11 & 0.00 & 94.44 & 5.56 \\
\hline 7 & $\mathrm{P}$ & EMAS & 37 & 8.11 & 29.73 & 27.03 & 43.24 & 54.05 & 45.95 \\
\hline 8 & $\mathrm{~F}$ & EMAS + ISO 14001 & 15 & 33.33 & 40.00 & 53.33 & 6.67 & 93.33 & 6.67 \\
\hline 9 & $\mathrm{O}$ & EMAS + ISO 14001 & 47 & 6.38 & 93.62 & 6.38 & 0.00 & 100.00 & 0.00 \\
\hline 10 & $\mathrm{C}$ & ISO 14001 & 11 & 72.73 & 45.45 & 27.27 & 27.27 & 63.64 & 36.36 \\
\hline 11 & $\mathrm{P}$ & EMAS + ISO 14001 & 11 & 18.18 & 27.27 & 18.18 & 54.55 & 54.55 & 45.45 \\
\hline 12 & A & EMAS + ISO 14001 & 38 & 5.26 & 5.26 & 10.53 & 81.58 & 21.05 & 78.95 \\
\hline 13 & $\mathrm{U}$ & EMAS + ISO 14001 & 11 & 45.45 & 45.45 & 18.18 & 36.36 & 72.73 & 27.27 \\
\hline 14 & $\mathrm{D}$ & EMAS + ISO 14001 & 24 & 37.50 & 25.00 & 29.17 & 45.83 & 50.00 & 50.00 \\
\hline 15 & $\mathrm{E}$ & EMAS + ISO 14001 & 14 & 21.43 & 28.57 & 71.43 & 0.00 & 92.86 & 7.14 \\
\hline 16 & $\mathrm{C}$ & EMAS + ISO 14001 & 13 & 53.85 & 38.46 & 53.85 & 7.69 & 84.62 & 15.38 \\
\hline Mean & & & 22.56 & 32.51 & 36.44 & 36.95 & 25.99 & 72.35 & 27.65 \\
\hline
\end{tabular}

by its suppliers only to a small extent. In case when a given environmental input aspect is classified as significant and a statement is made that "there is an issue with a supplier's technology" (and not, e.g. in the assumed transport scenario, on the supplier-manufacturer line), an organisation has a few possible ways of action: improvement of its manufacturing technology in order to minimise the use of input material, negotiations with its supplier in order to modernise their manufacturing technology, elimination of the necessity of using a certain material, and finding a supplier of an analogue material with better environmental characteristics. In the last two cases, the decisions lead to the end of cooperation with the current supplier, which is not always a desirable and feasible situation for an organisation.

The last reason for focusing on the output aspects might be the fact that they are more understandable from the environmental point of view. Taking into account the approaches and criteria used in the practice of assessing the environmental aspects, it is easier to analyse the elements related to waste and emissions, as their potential impact is more tangible and is disclosed to the public more often (the thinning of the layer zone, climate change, eutrophication, acidification). From this point of view, LCA creates a lot more analytical and interpretation possibilities. The use of LCA would require however a lot more precision and paying attention to detail while identifying environmental aspects. Because traditionally qualitative and semi-quantitative approaches are used, identifying environmental aspects in the quantitative way is not a priority. The problem relates mainly to the indirect environmental aspects, treated descriptively and qualitatively. In some cases, it can be as the result of not fully understanding environmental aspects and wrongly identifying them with areas of an organisation's operations. For instance, in the analysed registers there have been environmental aspects which could be classified as both input and output related (in Tables 1 and 2 described as others), e.g. heating of rooms, parameters of base fuel used in thermal energy production or a fire at an organisation). Such description of an aspect makes it impossible to express it in a quantitative way and is also difficult to interpret. For instance, heating of rooms includes at least three environmental aspects: use of fuel for heating, emissions to air, and waste produced as the result of the heating activities. From the point of view of LCA, in order to achieve the balance, at least the use of air used in combustion should be taken into account. Such types of environmental aspects difficult to classify would contribute about $8.16 \%$ (Polish examples) and 25.99\% (German examples) to all of the registered environmental aspects.

Another issue is the level of preparations of life cycle impact assessment (LCIA) methodologies in order to include environmental aspects appearing in environmental 
Table 3 Classification of economic activities in the European community (NACE; Eurostat: http://ec.europa.eu/eurostat/ramon/index.cfm? TargetUrl=DSP_PUB_WELC)

\begin{tabular}{ll}
\hline Symbol & Economic activity \\
\hline A & Agriculture, forestry and fishing \\
B & Mining and quarrying \\
C & Manufacturing \\
D & Electricity, gas, steam, and air \\
& conditioning supply \\
E & Water supply, sewerage, waste \\
& management, and remediation activities \\
F & Construction \\
G & Wholesale and retail trade; repair \\
& of motor vehicles and motorcycles \\
$\mathrm{H}$ & Transportation and storage \\
$\mathrm{I}$ & Accommodation and food service activities \\
$\mathrm{J}$ & Information and communication \\
$\mathrm{K}$ & Financial and insurance activities \\
$\mathrm{L}$ & Real estate activities \\
$\mathrm{M}$ & Professional, scientific, and technical activities \\
$\mathrm{N}$ & Administrative and support service activities \\
$\mathrm{O}$ & Public administration and defence; \\
$\mathrm{P}$ & compulsory social security \\
$\mathrm{Q}$ & Education \\
$\mathrm{R}$ & Human health and social work activities \\
$\mathrm{T}$ & Arts, entertainment, and recreation \\
& andifferentiated goods- and services-producing \\
& activities of households for own use \\
&
\end{tabular}

management systems. The key issue is the appearance of characterising factors for various environmental aspects. Within the scope of this paper, LCIA was carried out by using the Impact2002+ and Ecoinficator99 methodologies for the environmental aspects identified within ten organisations and it has been stated that the limitations are present regardless to whether environmental aspects are of input or output character. Taking into account the expediency of a fast and easy to interpret result, the methods used are the ones which give the score at a single level. In both of the mentioned methods, the lack of characterisation factors has been noted with regard to certain aspects often identified in organisations, for example: local water use, emission of water steam to air, emission of noise (non transport related) and odour, or certain forms of the waste management (especially hazardous waste). The aforementioned limitations might discourage from the use of LCA in the discussed area, so it is even more important to stimulate further development of LCIA methodologies. It seems that improvements in this area would significantly enhance the chance of popularisation of LCA as a tool for identification and assessment of environmental aspects in EMS.

\subsection{LCA-based assessment of environmental aspects identified by using a traditional approach}

The next step in this analysis was the assessment of environmental aspects with an LCA. In order to carry out the assessment, organisations were chosen for which it was possible to collect relevant quantitative data and enter in into LCA software. The analysis included environmental aspects from the registers and EMAS environmental declarations, so such which had been identified according with the traditional approach. The table below shows a sample organisation for which most detailed data had been gathered (organisation1 Table 1).

In a traditional approach used in the company by the environmental managers, three criteria of assessment were used. As presented in Table 4, these criteria were linked with a point scale in the following way: legal requirements (3-max, $0-\min$ ), stakeholders (2-max, $0-\min$ ), and

Table 4 The criteria of the environmental aspects assessment used in the company 1 (as traditional approach; Matuszak-Flejszman 2007)

\begin{tabular}{|c|c|c|}
\hline Criterion of assessment & Description & Number of points \\
\hline \multirow[t]{4}{*}{ Legal requirements } & No regulation exists & 0 \\
\hline & Legal regulation exists and it is fulfilled & 1 \\
\hline & Legal regulation exists and it is at risk of contravention & 2 \\
\hline & Legal regulation exists and it is broken & 3 \\
\hline \multirow[t]{3}{*}{ Interested parties } & Lack of interest & 0 \\
\hline & General interest exists & 1 \\
\hline & The claims are presented & 2 \\
\hline \multirow[t]{3}{*}{ Severity of the aspect } & Aspect is not hazardous & 0 \\
\hline & $\begin{array}{l}\text { Probably the aspect is not hazardous, but it could be, } \\
\text { if occurred in large scale or was be out of control }\end{array}$ & 1 \\
\hline & $\begin{array}{l}\text { Aspect can be recognised as hazardous - it reacts } \\
\text { with the environment and it impacts on the human health }\end{array}$ & 2 \\
\hline
\end{tabular}


the impact on the environment ( $2-\max , 0-\min )$. It has been decided that the significant environmental aspect is going to be the one, of which the total point count equals or is more than 3 , or it is equal to 2 in any of the criteria. What should be stressed is a fact that in this traditional approach assessing and assigning to point scale were performed in a descriptive way, without any impact modelling. The results obtained in this company are presented in Table 6 (as nonLCA-based approach).

In order to calculate the value of the environmental criterion based on LCA, SimaPro 7.0 has been used along with the Impact 2002+ (alongside with the sensitivity analysis carried out with the use of Ecoindicator99). The contribution analysis for the obtained LCIA results was carried out. Each of the percentage contribution was assigned a number of points, with accordance to the assumptions presented in Table 5.

In case of the analysed organisation, the analysis carried out by the environmental managers, showed 84 environmental aspects, out of which 75 were output related environmental aspects and the remaining nine were input related. Seventy-nine of the environmental aspects (94\%) were of quantitative character and five (mainly related to emergency situations) could not be expressed in a quantitative way and were excluded from LCA. Moreover, due to the organisation not agree to release detailed data for all of the environmental aspects, they were aggregated according to materials, e.g. rubber waste from various areas of the organisations' activity were added up (e.g. aggregated environmental aspect number 6 is the result of adding up of environmental aspects 6,7,8, and 9). The aggregation was also made while taking into account the assessment carried out within the organisation, which meant, the elements with different point values were not added up, thus, ensuring that the aggregated environmental aspects corresponded to the character of the environmental aspects from before the aggregation. As the result, the aggregation of 84 aspects gave the result of 65 . Subsequently, out of the 65 environmental aspects, the ones which, despite of their quantitative character, required detailed data, impossible to be provided by the organisation, e.g. the composition of the material in air filters (aspect 44), type and quantity of used filters, as well as car parts with regard to transport from suppliers (aspects 67-68) were excluded. As the result of these exclusions, the final list of 35 environmental aspects was received (Table 6), these were entered into LCA software and a LCIA was carried out. As a next step, a total single score has been calculated as a sum of ecoindicator values for all 35 aspects and a contribution analysis has been carried out in order to assess their significance. The results have been linked with a point scale (as presented in Table 5) and the significant environmental aspects have been identified. In the analyzed case study relevant differences have been observed in a kind and a number of aspects recognized as significant depending on the used approach (the aspects presented in bold in Table 6). Two points were assigned to these aspects with a share above $25 \%$ and they were recognised as significant while the aspects with a share between $10 \%$ and $25 \%$ got only one point and they were assessed as less significant.

Based on the results obtained from LCIA (Impact 2002+), the contribution analysis was carried out and each aspect was assigned an adequate number of points. Subsequently, the result was added up to the point values received for the remaining two criteria (legal requirements and stakeholders), and the significant environmental aspects were selected. Based on the assessment of 84 environmental aspects carried out by the organisation in a traditional way, 22 were selected as significant $(26.12 \%)$. In the LCA approach, out of the 35 environmental aspects taken into account in the final stage, four were found significant, which contributes to $11.42 \%$ of the overall number of the environmental aspects (the significant environmental aspects are: 5, 25, 33, and 35). As shown in the results in Table 4, only in case of the environmental aspect that five consistent results were obtained. All of the remaining environmental aspects were found significant in a traditional way or were not included in LCA (qualitative character, lack of relevant quantitative data) or resulted in a low ecoindicator value. In case of the environmental aspects 25 and 29, which were found insignificant by the organisation, a high contribution score was achieved $(7.229 \%$ and $5.313 \%)$ and they were assigned one point with regard to the environmental criterion. As the result, the environmental aspect number 25 was classified as significant, and in case of the environmental aspect 29-due to the 0 score with regard to the remaining two criteria, it was classified as insignificant. As mentioned above, the analysis of the
Table 5 Assumptions for assigning the results of contribution analysis and a point scale (ISO 14044:2006)

\begin{tabular}{lll}
\hline$\%$ contribution of aspect in the overall impact & Environmental aspects significance & Number of points \\
\hline Contribution $>50 \%$ & Largest impact & 2 \\
$25 \%<$ contribution $<50 \%$ & Significant impact & 2 \\
$10 \%<$ contribution $<25 \%$ & Some impact & 1 \\
$2.5 \%<$ contribution $<10 \%$ & Low impact & 1 \\
Contribution $<2.5 \%$ & Impact not taken into account & 0 \\
\hline
\end{tabular}


Table 6 Results of LCA-based assessment of environmental aspects identified by using of traditional methodology (according to ISO 14001)

\begin{tabular}{|c|c|c|c|c|c|c|c|c|}
\hline \multicolumn{5}{|c|}{ "Traditional" approach (ISO 14001)—case of company 1} & \multicolumn{4}{|c|}{ LCA based approach — case of company 1} \\
\hline ASPECT & $\begin{array}{l}\text { Legal } \\
\text { requirements }\end{array}$ & $\begin{array}{l}\text { Interested } \\
\text { parties }\end{array}$ & $\begin{array}{l}\text { Impact on environment } \\
\text { (non-LCA-based) }\end{array}$ & $\begin{array}{l}\text { Is the aspect } \\
\text { significant? }\end{array}$ & ASPECT & $\begin{array}{l}\text { Contribution } \\
\text { analysis [\%] }\end{array}$ & $\begin{array}{l}\text { Impact on environment } \\
\text { (LCA based) }\end{array}$ & $\begin{array}{l}\text { Is the aspect } \\
\text { significant? }\end{array}$ \\
\hline 1 & 1 & 1 & 0 & No & 1 & 0.087 & 0 & No \\
\hline 2 & 1 & 1 & 0 & No & & & & \\
\hline 3 & 1 & 1 & 0 & No & 2 & 0.011 & 0 & No \\
\hline 4 & 1 & 1 & 0 & No & 3 & 0.086 & 0 & No \\
\hline 5 & 0 & 0 & 0 & No & 4 & 0.094 & 0 & No \\
\hline 6 & 1 & 1 & 1 & Yes & 5 & 35.445 & 2 & Yes \\
\hline 7 & 1 & 1 & 1 & & & & & \\
\hline 8 & 1 & 1 & 1 & & & & & \\
\hline 9 & 1 & 1 & 1 & & & & & \\
\hline 10 & 1 & 0 & 0 & No & 6 & 0.000 & 0 & No \\
\hline 11 & 1 & 1 & 0 & No & 7 & 0.008 & 0 & No \\
\hline 12 & 1 & 1 & 0 & No & 8 & -0.263 & 0 & No \\
\hline 13 & 1 & 1 & 0 & & & & & \\
\hline 14 & 1 & 1 & 0 & No & 9 & 0.225 & 0 & No \\
\hline 15 & 1 & 1 & 0 & & & & & \\
\hline 16 & 1 & 1 & 0 & & & & & \\
\hline 17 & 1 & 1 & 0 & No & - & - & - & - \\
\hline 18 & 0 & 1 & 2 & Yes & - & - & - & - \\
\hline 19 & 0 & 1 & 2 & & & & & \\
\hline 20 & 0 & 1 & 2 & & & & & \\
\hline 21 & 1 & 0 & 2 & Yes & - & - & - & - \\
\hline 22 & 1 & 0 & 2 & & & & & \\
\hline 23 & 1 & 0 & 2 & & & & & \\
\hline 24 & 0 & 1 & 1 & No & 10 & 0.000 & 0 & No \\
\hline 25 & 1 & 0 & 1 & No & - & - & - & - \\
\hline 26 & 1 & 0 & 1 & No & 11 & 0.009 & 0 & No \\
\hline 27 & 1 & 1 & 0 & No & 12 & 0.002 & 0 & No \\
\hline 28 & 1 & 0 & 0 & No & 13 & 0.001 & 0 & No \\
\hline 29 & 1 & 0 & 0 & & & & & \\
\hline 30 & 1 & 0 & 0 & & & & & \\
\hline 31 & 1 & 1 & 0 & No & 14 & 0.000 & 0 & No \\
\hline 32 & 0 & 0 & 1 & No & - & - & - & - \\
\hline 33 & 1 & 1 & 0 & No & 15 & 0.340 & 0 & No \\
\hline 34 & 1 & 1 & 0 & & & & & \\
\hline 35 & 1 & 1 & 0 & & & & & \\
\hline 36 & 1 & 1 & 0 & & & & & \\
\hline 37 & 1 & 1 & 2 & Yes & - & - & - & - \\
\hline 38 & 1 & 1 & 2 & Yes & 16 & 0.026 & 0 & No \\
\hline 39 & 1 & 1 & 2 & & & & & \\
\hline 40 & 1 & 1 & 2 & & & & & \\
\hline 41 & 1 & 1 & 2 & & & & & \\
\hline 42 & 1 & 1 & 2 & & & & & \\
\hline 43 & 1 & 1 & 2 & & & & & \\
\hline 44 & 1 & 1 & 0 & No & - & - & - & - \\
\hline 45 & 1 & 0 & 0 & No & 17 & 0.000 & 0 & No \\
\hline 46 & 1 & 0 & 0 & No & & & & \\
\hline 47 & 1 & 0 & 2 & Yes & 18 & 0.004 & 0 & No \\
\hline 48 & 1 & 0 & 1 & No & - & - & - & No \\
\hline
\end{tabular}


Table 6 (continued)

\begin{tabular}{|c|c|c|c|c|c|c|c|c|}
\hline \multicolumn{5}{|c|}{ "Traditional" approach (ISO 14001) — case of company 1} & \multicolumn{4}{|c|}{ LCA based approach — case of company 1} \\
\hline ASPECT & $\begin{array}{l}\text { Legal } \\
\text { requirements }\end{array}$ & $\begin{array}{l}\text { Interested } \\
\text { parties }\end{array}$ & $\begin{array}{l}\text { Impact on environment } \\
\text { (non-LCA-based) }\end{array}$ & $\begin{array}{l}\text { Is the aspect } \\
\text { significant? }\end{array}$ & ASPECT & $\begin{array}{l}\text { Contribution } \\
\text { analysis [\%] }\end{array}$ & $\begin{array}{l}\text { Impact on environment } \\
\text { (LCA based) }\end{array}$ & $\begin{array}{l}\text { Is the aspect } \\
\text { significant? }\end{array}$ \\
\hline 49 & 1 & 1 & 2 & \multirow[t]{2}{*}{ Yes } & \multirow[t]{2}{*}{19} & \multirow[t]{2}{*}{0.000} & \multirow[t]{2}{*}{0} & \multirow[t]{2}{*}{ No } \\
\hline 50 & 1 & 1 & 2 & & & & & \\
\hline 51 & 1 & 1 & 1 & Yes & 20 & 0.000 & 0 & No \\
\hline 52 & 1 & 0 & 1 & No & 21 & 0.004 & 0 & No \\
\hline 53 & 1 & 1 & 0 & No & 22 & 0.004 & 0 & No \\
\hline 54 & 0 & 0 & 0 & No & 23 & 0.102 & 0 & No \\
\hline 55 & 1 & 1 & 0 & No & 24 & 0.172 & 0 & No \\
\hline 56 & 1 & 1 & 0 & No & 25 & 7.229 & 1 & Yes \\
\hline 57 & 1 & 0 & 0 & No & - & - & - & - \\
\hline 58 & 1 & 1 & 2 & Yes & - & - & - & - \\
\hline 59 & 0 & 0 & 1 & No & - & - & - & - \\
\hline 60 & 1 & 0 & 0 & No & - & - & - & - \\
\hline 61 & 1 & 0 & 1 & No & 26 & 0.002 & 0 & No \\
\hline 62 & 1 & 1 & 0 & No & - & - & - & - \\
\hline 63 & 1 & 0 & 1 & No & - & - & - & - \\
\hline 64 & 1 & 0 & 1 & No & 27 & 0.001 & 0 & \\
\hline 65 & 1 & 0 & 1 & No & - & - & - & - \\
\hline 66 & 0 & 0 & 0 & No & - & - & - & - \\
\hline 67 & 0 & 0 & 0 & No & - & - & - & - \\
\hline 68 & 0 & 0 & 0 & No & - & - & - & - \\
\hline 69 & 0 & 0 & 0 & No & 28 & 0.000 & 0 & No \\
\hline 70 & 0 & 0 & 0 & No & 29 & 5.313 & 1 & No \\
\hline 71 & 0 & 0 & 0 & No & - & - & - & - \\
\hline 72 & 0 & 0 & 0 & No & - & - & - & - \\
\hline 73 & 0 & 0 & 0 & No & - & - & - & - \\
\hline 74 & 0 & 0 & 0 & No & - & - & - & - \\
\hline 75 & 0 & 0 & 0 & No & 30 & 0.004 & 0 & No \\
\hline 76 & 0 & 0 & 0 & No & 31 & 0.077 & 0 & No \\
\hline 77 & 1 & 1 & 0 & No & 32 & 0.000 & 0 & No \\
\hline 78 & 1 & 1 & 0 & & & & & \\
\hline 79 & 1 & 1 & 0 & & & & & \\
\hline 80 & 1 & 1 & 0 & No & 33 & 47.874 & 2 & Yes \\
\hline 81 & 1 & 1 & 0 & & & & & \\
\hline 82 & 1 & 1 & 0 & No & 34 & 0.012 & 0 & No \\
\hline 83 & 1 & 1 & 0 & & & & & \\
\hline 84 & 1 & 1 & 0 & No & 35 & 3.132 & 1 & Yes \\
\hline \multicolumn{4}{|c|}{ Total number of aspects } & 84 & \multicolumn{3}{|c|}{ Total number of aspects } & 35 \\
\hline \multicolumn{4}{|c|}{ Input related aspects [\%] } & 10.71 & \multicolumn{3}{|c|}{ Input related aspects [\%] } & 17.14 \\
\hline \multicolumn{4}{|c|}{ Output related aspects [\%] } & 89.29 & \multicolumn{3}{|c|}{ Output related aspects $[\%]$} & 82.86 \\
\hline
\end{tabular}

available environmental registers has shown that from the LCA point of view, the input elements are often excluded although they can become significant environmental aspects. That is why it has been decided to carry out additionally identification of environmental aspects with the use of analysis described in Part 1 of this article - in accordance with LCA methodology.
2.3 Identification and assessment of environmental aspects with the use of LCA approach

For the above-described organisation, both stages of analysis with the use of LCA were carried out: identification and assessment of environmental aspects. Where possible, the quantitative data was collected. We have 
Table 7 The result of environmental aspect's identification and assessment based on LCA approach

\begin{tabular}{|c|c|c|c|c|c|c|c|c|}
\hline \multirow[t]{2}{*}{ ASPECT } & \multicolumn{4}{|c|}{ "Traditional" approach (ISO 14001) — case of company 1} & \multicolumn{4}{|c|}{ LCA based approach—case of company 1} \\
\hline & $\begin{array}{l}\text { Contribution } \\
\text { analysis [\%] }\end{array}$ & Type of aspect & $\begin{array}{l}\text { Impact on environment } \\
\text { (non-LCA-based } \\
\text { identification) }\end{array}$ & $\begin{array}{l}\text { Is the aspect } \\
\text { significant? }\end{array}$ & $\begin{array}{l}\text { Contribution } \\
\text { analysis [\%] }\end{array}$ & $\begin{array}{l}\text { Type of } \\
\text { aspect }\end{array}$ & $\begin{array}{l}\text { Impact on environment } \\
\text { (LCA based } \\
\text { identification) }\end{array}$ & $\begin{array}{l}\text { Is the aspect } \\
\text { significant? }\end{array}$ \\
\hline 1 & 0.087 & Output & 0 & No & 0.039 & Output & 0 & No \\
\hline 2 & 0.011 & Output & 0 & No & 0.005 & Output & 0 & No \\
\hline 3 & 0.086 & Output & 0 & No & 0.039 & Output & 0 & No \\
\hline 4 & 0.094 & Output & 0 & No & 0.042 & Output & 0 & No \\
\hline 5 & 35.445 & Output & 2 & Yes & 15.889 & Output & 1 & Yes \\
\hline 6 & 0.000 & Output & 0 & No & 0.000 & Output & 0 & No \\
\hline 7 & 0.008 & Output & 0 & No & 0.004 & Output & 0 & No \\
\hline 8 & -0.263 & Output & 0 & No & -0.118 & Output & 0 & No \\
\hline 9 & 0.225 & Output & 0 & No & 0.101 & Output & 0 & No \\
\hline 10 & 0.000 & Output & 0 & No & 0.000 & Output & 0 & No \\
\hline 11 & 0.009 & Output & 0 & No & 0.004 & Output & 0 & No \\
\hline 12 & 0.002 & Output & 0 & No & 0.001 & Output & 0 & No \\
\hline 13 & 0.001 & Output & 0 & No & 0.000 & Output & 0 & No \\
\hline 14 & 0.000 & Output & 0 & No & 0.000 & Output & 0 & No \\
\hline 15 & 0.340 & Output & 0 & No & 0.152 & Output & 0 & No \\
\hline 16 & 0.026 & Output & 0 & No & 0.011 & Output & 0 & No \\
\hline 17 & 0.000 & Output & 0 & No & 0.000 & Output & 0 & No \\
\hline 18 & 0.004 & Output & 0 & No & 0.002 & Output & 0 & No \\
\hline 19 & 0.000 & Output & 0 & No & 0.001 & Output & 0 & No \\
\hline 20 & 0.000 & Output & 0 & No & 0.000 & Output & 0 & No \\
\hline 21 & 0.004 & Output & 0 & No & 0.002 & Output & 0 & No \\
\hline 22 & 0.004 & Output & 0 & No & 0.002 & Output & 0 & No \\
\hline 23 & 0.102 & Input & 0 & No & 0.046 & Input & 0 & No \\
\hline 24 & 0.172 & Output & 0 & No & 0.077 & Output & 0 & No \\
\hline 25 & 7.229 & Output & 1 & Yes & 3.240 & Output & 1 & Yes \\
\hline 26 & 0.002 & Output & 0 & No & 0.001 & Output & 0 & No \\
\hline 27 & 0.001 & Output & 0 & No & 0.001 & Output & 0 & No \\
\hline 28 & 0.000 & Output & 0 & No & 0.000 & Output & 0 & No \\
\hline 29 & 5.313 & Output & 1 & No & 2.553 & Output & 1 & No \\
\hline 30 & 0.004 & Output & 0 & No & 0.002 & Output & 0 & No \\
\hline 31 & 0.077 & Input & 0 & No & 0.034 & Input & 0 & No \\
\hline 32 & 0.000 & Input & 0 & No & 0.000 & Input & 0 & No \\
\hline 33 & 47.874 & Input & 2 & Yes & 21.461 & Input & 1 & Yes \\
\hline 34 & 0.012 & Input & 0 & No & 0.005 & Input & 0 & No \\
\hline 35 & 3.132 & Input & 1 & Yes & 1.404 & Input & 0 & No \\
\hline 36 & - & - & - & - & 0.000 & Input & 0 & No \\
\hline 37 & - & - & - & - & 0.000 & Input & 0 & No \\
\hline 38 & - & - & - & - & 0.036 & Input & 0 & No \\
\hline 39 & - & - & - & - & 2.726 & Input & 1 & Yes \\
\hline 40 & - & - & - & - & 1.195 & Input & 0 & No \\
\hline 41 & - & - & - & - & 0.184 & Input & 0 & No \\
\hline 42 & - & - & - & - & 50.257 & Input & 2 & Yes \\
\hline 43 & - & - & - & - & 0.179 & Input & 0 & No \\
\hline 44 & - & - & - & - & 0.031 & Input & 0 & No \\
\hline 45 & - & - & - & - & 0.291 & Input & 0 & No \\
\hline 46 & - & - & - & - & 0.040 & Input & 0 & No \\
\hline 47 & - & - & - & - & 0.029 & Input & 0 & No \\
\hline 48 & - & - & - & - & 0.019 & Input & 0 & No \\
\hline 49 & - & - & - & - & 0.000 & Input & 0 & No \\
\hline 50 & - & - & - & - & 0.001 & Input & 0 & No \\
\hline
\end{tabular}


Table 7 (continued)

\begin{tabular}{|c|c|c|c|c|c|c|c|c|}
\hline \multirow[t]{2}{*}{ ASPECT } & \multicolumn{4}{|c|}{ "Traditional" approach (ISO 14001) — case of company 1} & \multicolumn{4}{|c|}{ LCA based approach—case of company 1} \\
\hline & $\begin{array}{l}\text { Contribution } \\
\text { analysis [\%] }\end{array}$ & Type of aspect & $\begin{array}{l}\text { Impact on environment } \\
\text { (non-LCA-based } \\
\text { identification) }\end{array}$ & $\begin{array}{l}\text { Is the aspect } \\
\text { significant? }\end{array}$ & $\begin{array}{l}\text { Contribution } \\
\text { analysis [\%] }\end{array}$ & $\begin{array}{l}\text { Type of } \\
\text { aspect }\end{array}$ & $\begin{array}{l}\text { Impact on environment } \\
\text { (LCA based } \\
\text { identification) }\end{array}$ & $\begin{array}{l}\text { Is the aspect } \\
\text { significant? }\end{array}$ \\
\hline 51 & - & - & - & - & 0.003 & Input & 0 & No \\
\hline 52 & - & - & - & - & 0.006 & Input & 0 & No \\
\hline 53 & - & - & - & - & 0.005 & Input & 0 & No \\
\hline \multicolumn{2}{|c|}{ Total number of aspects } & 35 & & & Total number of aspects & 53 & & \\
\hline \multicolumn{2}{|c|}{ Input related aspects [\%] } & 17.14 & & & Input related aspects $[\%]$ & 45.28 & & \\
\hline \multicolumn{2}{|c|}{ Output related aspects $[\%]$} & 82.86 & & & Output related aspects $[\%]$ & 54.71 & & \\
\hline \multicolumn{2}{|c|}{ Single score $[\mathrm{Pt}]$} & 456.56 & & & Single score $[\mathrm{Pt}]$ & 1018.47 & & \\
\hline
\end{tabular}

excluded the qualitative environmental aspects and aspects which for various reasons could not be expressed in a quantitative way (the aggregation level of environmental aspects from point 2.2. has been retained). The input environmental aspects were assigned relevant output aspects and vice versa (what resulted in a total number of aspects equalled 53). Thanks to that the mass balancing of the whole management system was achieved. The function and functional unit were referred to a period of a half year of the organisation's activity and they were defined as: the organisation's operation in the first half of 2009. The collected and calculated data was referred to the range (the presented results refer to the planned values so the ones which at the time of identification and assessment were assumed to appear in the period expressed by a functional unit. Due to the fact that the analyses were carried out in the first half of 2009, additional assessments for actual values, which actually happened, have been also carried out). Similarly as in a case of the results presented in Table 6, also in relation to data shown in Table 7 , it is possible to make a comparison in a kind and a number of significant aspects selected by using two mentioned approaches (aspects bolded in Table 7). It is worth emphasizing a high convergence of the assessment's results for the first 35 aspects.

The results presented in Table 7 show that the identification of additional 18 environmental input aspects has resulted in increasing of the value of the ecoindicator from 456.56 $\mathrm{Pt}$ to $1,018.47 \mathrm{Pt}$ and the change in contribution of various environmental aspects in the overall impact on the environment. As the result, the environmental aspect 35 lost their significant status, and the remaining ones, classified as significant in 2.2, retained their score. Additionally, two environmental aspects were selected from among the additionally identified ones. As it can be observed, the impact on the environment after the identification based on LCA methodology increased twice fold. As shown in Fig. 1, "truncation error" consequential not to omission of the environmental input aspects was $123 \%$.

\section{Final conclusions}

Based on the assessments carried out and the observations made, the following final conclusions have been drawn with regard to the possibility of use and usefulness of LCA methodology in the discussed area and in the light of the requirements relating to the environmental performance's indicators (Jasch 2000). LCA has obvious advantages such as:

- The possibility of assessing the environmental aspects from the life cycle perspective what encourages looking at their technological history placed in other LC stages and to gather appropriate data

- The inclusion of the life cycle perspective allows to transcend the boundaries of the company and to cover, using a common quantitative analysis, both the direct and indirect environmental aspects

- LCA offers sophisticated and well-established impact assessment methodology, making the results of the environmental aspects assessment reliable and scientifically relevant

- Standardised methodology which can be used with regards to both identification and assessment of environmental impact

- Inclusion of the quantitative information with regard to environmental aspects as well as obtaining the final

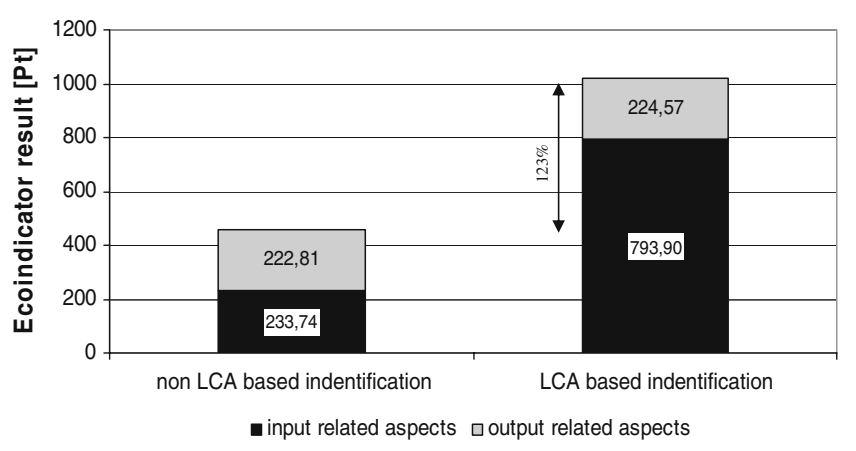

Fig. 1 The difference in the level of environmental impact for environmental aspects - with and without LCA-based identification 
data with regard to the significance of the impact on the environment (possibility of a result expressed by 1 number only)

- Availability of software supporting the assessment

- Presence of some methodical steps enabling the verification of the collected data (balancing, assessment of data quality, allocation procedures)

- Generating of reproducible results

As observed through the assessment, LCA has also a number of limitations with regard to identification and assessment of environmental aspect in the environmental management systems.

The main ones include:

- The complexity of the procedure

- Time consumption (data gathering, carrying out of the assessments)

- Higher cost (especially during the first ever assessment)

- Not possible to assess of environmental aspects with the qualitative character and these related to emergency situations

- Limitation related to the lack of relevant parameters in the currently used LCIA methods and a risk that the methods may not capture all environmental impacts well

The time and cost related to LCA are the highest at the beginning, during the first assessment. The cost of purchasing software, training, and acquiring of data is generally borne at the beginning. Whilst gaining experience and creating own database, the effort related to LCA decreases disproportionately. The most serious limitation seems to be the issue of identifying of environmental qualitative aspects and those which are difficult to express in a quantitative way. This applies mainly to emergency situations. Perhaps, the solution would be to assume that environmental aspects related to emergency situations are significant without carrying out LCA for these elements. This is often assumed during assessments of environmental aspects carried out in a traditional way. Taking into account the fact that in practice they do gain this status, this solution is worth considering. The issue seems to be a relatively small number of significant environmental aspects selected from the whole list of environmental aspects identified with the use of methodology based on LCA. It is however more of an issue of criteria accepted when interpreting the results of the contribution analysis, then the issues within the methodology of the tool. It seems that, because of the listed limitations, LCA may cause scepticism among the environmental managers who have not had experienced dealing with this technique. None of the analysed organisations has used LCA in the discussed area. This referred not only to organisations operating from Poland but also from Germany, where organisations have more experience with regard to eco-balance methodologies. It seems that a larger number of analogue assessments should in practice verify the usefulness of LCA within the identification and assessment of environmental aspects, especially because the interest in the possibility of using LCA for assessment of environmental aspects is increasing more and more.

Taking into account all these observations, it can be recapitulated that an ideal result would be not a replacement of the traditional approaches by LCA but a smart combination of them. Some points are better captured in EMAS than in LCA, so it seems that further work is needed.

Open Access This article is distributed under the terms of the Creative Commons Attribution Noncommercial License which permits any noncommercial use, distribution, and reproduction in any medium, provided the original author(s) and source are credited.

\section{References}

EMAS (2008) Proposal for a regulation of the European Parliament and of the council on the voluntary participation by organizations in a Community eco-management and audit scheme (EMAS); Brussels COM (2008) 402/2

International Standard Organization (2004) ISO 14004: Environmental managemenet systems - general guidelines on principles, systems and supporting techniques

International Standard Organization (2004) ISO 14001: environmental management systems - requirements with guidance for use

International Standard Organization (2006) ISO 14044: environmental management - life cycle assessment - requirements and guidelines

Jasch C (2000) Environmental performance evaluation and indicators. J Clean Prod 8:79-88

Matuszak-Flejszman A (2007) Environmental management system in organization (Polish); Publishing house of Poznan University of Economics; Poznan; Poland; ISBN: 9788374172660 